\title{
REVIEW OF THE PRODUCTION OF BIODIESEL FROM WASTE COOKING OIL USING SOLID CATALYSTS
}

\author{
N.H. Said ${ }^{1,3}$,F.N. Ani ${ }^{*}$ and M.F.M. Said ${ }^{2}$ \\ ${ }^{1}$ Department of Thermodynamics and Fluid Mechanics, \\ ${ }^{2}$ Department of Automotive Engineering \\ Faculty of Mechanical Engineering \\ Universiti Teknologi Malaysia, \\ Skudai 81310 Johor, Malaysia \\ Email:*farid@mail.fkm.utm.my \\ ${ }^{3}$ Department of Mechanical Engineering \\ State Polytechnic of Ujung Pandang, \\ Makassar 90245, Indonesia
}

\begin{abstract}
The need for fossil fuels and the emissions generated from these fuels are increasing daily. Researchers are concerned with global warming as well as climate change; and energy sustainability and material usages are important issues today. Waste cooking oil (WCO) can be processed into biodiesel as an alternative fuel to replace diesel. Production of biodiesel using WCO as the feedstock has been of growing interest for the last two decades. A number of research papers related to the improvements in production, raw materials and catalyst selection have been published. This paper reviews the various types of heterogeneous solid catalyst in the production of biodiesel via the transesterification of WCO. The catalysts used can be classified according to their state presence in the transesterification reaction as homogeneous or heterogeneous catalysts. Homogeneous catalysts act in the same liquid phase as the reaction mixture, whereas heterogeneous catalysts act in a solid phase with the reaction mixture. Heterogeneous catalysts are non-corrosive, a green process and environmentally friendly. They can be recycled and used several times, thus offering a more economic pathway for biodiesel production. The advantages and drawbacks of these heterogeneous catalysts are presented. Future work focuses on the application of economically and environmentally friendly solid catalysts in the production of biodiesel using WCO as the raw material.
\end{abstract}

Keywords: Transesterification, waste cooking oil, heterogeneous catalyst, biodiesel.

\section{INTRODUCTION}

The need for energy is increasing continuously due to increased industrialization activity and population growth. In addition to the issue of global warming, scientists are encouraged to develop fuel substitutes that are renewable and sustainable [1, 2]. Waste cooking oil (WCO) is generated locally wherever food is cooked or fried in oils. These are derived from vegetable oil (i.e. soybean, cottonseed, groundnut, sunflower, rapeseed, sesame, corn, olive, palm, palm kernel, coconut, linseed, castor, and soy among a wide variety of plant sources) and animal fats/oils (i.e. butter, lard, tallow, grease and fish oil) [3-5]. WCOs and fats cause disposal problems in many parts of the world. These problems could be changed into both economic and environmental 
benefits by proper utilization and management of $\mathrm{WCO}$ as a fuel substitute. Many developed countries have set policies that penalize the disposal of WCO into waste drainage [2].

Biodiesel is the name for a variety of ester-based oxygenated fuels from renewable biological sources. Chemically, biodiesel is defined as the monoalkyl esters of long-chain fatty acids derived from renewable biolipids. Typically, it is produced through the reaction of a vegetable oil or animal fat with methanol or ethanol in the presence of a catalyst to yield methyl or ethyl esters (biodiesel) and glycerin. Fatty acid methyl esters [6] or biodiesels from processed organic oil are produced from a vegetable oil or animal fats [7]. Biodiesel is similar to petroleum diesel in many aspects of its chemical and physical properties [8,9].

Engine performance and fuel consumption were favorable making it a better substitute diesel [10-15]. There are at least four ways in which oils and fats can be converted to biodiesel namely: pyrolysis (thermal cracking), microemulsification, dilution and transesterification [16, 17]. However, transesterification is the best method for producing higher quality biodiesel [18]. Transesterification (also called alcoholysis) is the reaction of a fat or oil with an alcohol to form esters and glycerol. Commonly, the reaction rate and yield can be improved by using a catalyst. It consists of a number of consecutive, reversible reactions. The triglycerides are converted step wise to triglycerides, monoglycerides and finally glycerol [17]. The main catalysts used can be classified, according to their chemical presence in the transesterification reaction, as homogeneous or heterogeneous catalysts. Homogeneous catalysts act in the same liquid phase as the reaction mixture, whereas heterogeneous catalysts act in a different phase from the reaction mixture, usually as a solid [19]. Heterogeneous catalysts are noncorrosive, a green process and environmentally friendly. They can be recycled and used several times, thus offering a more economic pathway for biodiesel production. From the process point of view, to recover the catalyst it is not necessary to undertake aqueous treatment and purification steps so giving more simplified and very high yields of methyl esters $[20,21]$. This review presents the recent publications dealing with the application of solid catalysts in biodiesel production from transesterification of WCOs as the raw material.

\section{BIODIESEL PRODUCTION FROM WCO}

WCO, which is very much cheaper than pure vegetable oil, is a promising alternative to vegetable oil for biodiesel production. Biodiesel can be produced by transesterification using alkaline, acidic, and enzymatic catalysts [1]. The various methods of biodiesel production from WCO can be divided into three main groups: (a) homogeneous, (b) heterogonous and (c) non-catalytic transesterifications. Several types of catalysts have been widely used for biodiesel production from WCOs. Base homogenous catalysts face a major challenge in terms of the FFA and water content of the oil. Therefore, a twostep process may overcome this challenge [18, 22]. Talebian-Kiakalaieh et al. [18] reported that utilizing WCO as the raw material can decrease biodiesel production costs. However, it has obstacles such as the high FFA and water content. Therefore, these obstacles increase the cost of the purification and separation processes downstream of biodiesel production. 


\section{WCO PROCESSING USING HETEROGENEOUS CATALYSTS}

The application of heterogeneous catalysts in biodiesel production from WCO have advantages over homogenous catalysts in terms of the higher biodiesel yield; the higher glycerol purity, easier catalyst separation and recovery; being cheaper, safer, and more environmentally friendly and not requiring a washing step for the crude ester. Moreover, these catalysts can eliminate saponification and hydrolysis reactions [22]. According to Talebian-Kiakalaieh et al. [18] solid catalysts should have characteristics such as an interconnected system of large pores, a medium to high concentration of strong acid sites, a hydrophobic surface, and the ability to regulate the hydrophobicity of the surface to prevent the deactivation process. Heterogeneous acid catalysts can include various types of process, such as ion exchange resins and sulfated oxides, while the heterogeneous base catalysts consist of several kinds, among which are the earth metal oxides and their derivatives, mixed metal oxides and their derivatives, and alkali metal oxides and their derivatives, that have been used in various biodiesel production processes.

The heterogeneously catalyzed methanolysis reaction of transesterification is very complex. It includes a three-phase system, such as the one solid phase (heterogeneous catalyst) and two immiscible liquid phases (oil and methanol). Also, concurrent with methanolysis, some side reactions, such as the saponification of glycerides and methyl esters and the neutralization of free fatty acids by catalyst take place [21]. Lam et al. [4] reviewed the application of homogeneous, heterogeneous and enzymatic catalysis for transesterification of high FFA oil, such as WCO, to biodiesel. The authors stated that some of the heterogeneous acid and enzyme catalysis systems still experience problems with regard to mass transfer and, therefore, are not suitable for industrial applications. The heterogeneous catalysts can be classified into heterogeneous base catalysts and heterogeneous acid catalysts. Table 1 presents several research works on solid catalysts used in the transesterification of WCO. Some catalysts are from natural resources, while others are synthesized.

\section{The Heterogeneous Base Catalyst}

Generally, heterogeneous base catalysts are produced in different ways, such as impregnation of amounts of base metals, precipitation, conversion to oxides by calcination, and co-precipitation. Borges and Díaz [23] used potassium-loaded pumice material (K-Pumice) as the heterogeneous catalyst in the sunflower oil and waste oil transesterification reaction for biodiesel production, using a packed-bed catalytic reactor in a recirculation system. Pumice particles $(1.40-3.0 \mathrm{~mm})$ were introduced into a potassium hydroxide aqueous solution in order to achieve potassium interchange, creating some basic sites on the natural material. The reaction conversion increased slightly when the temperature was increased from 50 to $60^{\circ} \mathrm{C}$. However, using a $55^{\circ} \mathrm{C}$ reaction temperature, a $2 \mathrm{hr}$ reaction time, 20:1 methanol/oil molar ratio, and an $8.2 \mathrm{~cm}$ catalytic packed-bed length, the value of the content of the biodiesel in FAME required by Standard UNE-EN $14124(96.5 \%)$ was achieved, reaching a 99.5\% value. Roschat et al. [24] undertook transesterification, combining WCO, palm oil, soybean oil and rice bran with methanol to make a biodiesel and glycerol by-product, using calcined waste coral fragments in solid form as the catalyst. Under optimum reaction conditions, coral fragments calcined at $700{ }^{\circ} \mathrm{C}$ for $1 \mathrm{hr}$, a catalyst/oil ratio of $100 \mathrm{wt} . \%$, a methanol/oil 
molar ratio of $15: 1$, and a reaction temperature of $65^{\circ} \mathrm{C}$ with constant stirring, biodiesel with a FAME yield of over $98 \%$ in $2 \mathrm{hr}$ can be produced.

The synthesized mixed oxide catalysts comprising $\mathrm{CaO}$ and $\mathrm{ZrO} 2$ mixed oxides with various Ca-to-Zr molar ratios were used for the transesterification of $\mathrm{WCO}$ as the feedstock with methanol to produce biodiesel at $65{ }^{\circ} \mathrm{C}$ and $1 \mathrm{~atm}$. The experimental results indicated that the activity of synthesized catalysts increases as the Ca-to- $\mathrm{Zr}$ molar ratio increases but at the same time the stability of the catalysts decreases. Under the appropriate transesterification conditions at $65{ }^{\circ} \mathrm{C}$, catalyst loading $=10 \mathrm{wt} . \%$, methanol-to-oil molar ratio $=30: 1$, and reaction time $=2 \mathrm{hr}$, a biodiesel yield of $92.1 \%$ could be achieved over the $\mathrm{CaO}-\mathrm{ZrO} 2$ catalyst with a Ca-to- $\mathrm{Zr}$ molar ratio of 0.5 . Other results obtained in this experiment show that synthesized catalysts can be used as recyclable, stable, and active catalysts for the production of biodiesel from WCO [27].

Table 1 . The heterogeneous base catalysts and heterogeneous acid catalysts used in transesterification of WCO.

\begin{tabular}{|c|c|}
\hline Catalyst & References \\
\hline \multicolumn{2}{|l|}{ Heterogeneous base catalysts } \\
\hline Calcium oxide $(\mathrm{CaO})$ & {$[25]$} \\
\hline Basic solid $\mathrm{Mg}-\mathrm{Al}-\mathrm{CO}_{3}$ hydrotalcite catalysts in powder form & [26] \\
\hline $\mathrm{CaO}$ and $\mathrm{ZrO}_{2}$ mixed oxides with various Ca-to- $\mathrm{Zr}$ & {$[27]$} \\
\hline Barium meliorated construction site waste marble & [28] \\
\hline Potassium-loaded pumice material (K-Pumice) & {$[23]$} \\
\hline Strontiumzirconia $\left(\mathrm{Sr} / \mathrm{ZrO}_{2}\right)$ catalyst & [29] \\
\hline Palm ash from empty fruit bunches & {$[30]$} \\
\hline Calcium oxide supported on activated carbon $(\mathrm{CaO} / \mathrm{AC})$ & [31] \\
\hline Calcium ethoxide & [32] \\
\hline An agglomerated $\mathrm{Zr}-\mathrm{SBA}-15 /$ bentonite catalyst & [33] \\
\hline Calcined waste coral fragments & [24] \\
\hline \multicolumn{2}{|l|}{ Heterogeneous acid catalysts } \\
\hline $\mathrm{WO}_{3} / \mathrm{ZrO}_{2} . \mathrm{WO}_{3} / \mathrm{ZrO}_{2}-\mathrm{Al}_{2} \mathrm{O}_{3} . \mathrm{MoO}_{3} / \mathrm{ZrO}_{2}$ & {$[34]$} \\
\hline $\mathrm{MoO}_{3} / \mathrm{SiO}_{2}$. TPA $/ \mathrm{ZrO}_{2}$. Zinc stearate/SiO $\mathrm{S}_{2}$ Zinc ethanoate/SiO${ }_{2}$. & \\
\hline Tri-potassium phosphate & {$[35]$} \\
\hline $\begin{array}{l}\text { Carbohydrate-derived catalysts from various carbohydrates such as D- } \\
\text { glucose, sucrose, cellulose and starch }\end{array}$ & {$[36]$} \\
\hline Zinc aluminate catalyst & {$[37]$} \\
\hline Mg MCM-41, Mg-Al hydrotalcite, and K+ impregnated zirconia & {$[38]$} \\
\hline Aminophosphonic acid resin D418 & [39] \\
\hline Solid acid resins: Amberlyst ${ }^{\circledR} 15$ and Amberlyst ${ }^{\circledR} 46$ and Purolite ${ }^{\circledR}$ D5081 & {$[40]$} \\
\hline Sulfonating pyrolyzed rice husk with concentrated sulfuric acid & [41] \\
\hline $\mathrm{SO}_{2}^{4} / \mathrm{Al}_{2} \mathrm{O}_{3} . \mathrm{SO}_{2}^{4} / \mathrm{SiO}_{2}$. H-zeolite, $\mathrm{SO}_{2}^{4} / \mathrm{ZrO}_{2}$ & [42] \\
\hline $\mathrm{WO}_{3} / \mathrm{ZrO}_{2}$. Csheteropoly acid & \\
\hline Y-type zeolites with $\mathrm{Al}_{2} \mathrm{O}_{3}$ and $\mathrm{Na}_{2} \mathrm{O}$ & {$[26]$} \\
\hline Mixed oxides of $\mathrm{TiO}_{2}-\mathrm{MgO}$ & {$[43]$} \\
\hline $\begin{array}{l}\text { A solid zirconiumdodecatungstophosphate } \mathrm{Zr}_{0.7} \mathrm{H}_{0.2} \mathrm{PW}_{12} \mathrm{O}_{40} \\
\text { (abbreviated as } \mathrm{ZrHPW} \text { ) }\end{array}$ & [44] \\
\hline
\end{tabular}


Wan Nor Nadyaini and Nor Aishah [29] undertook transesterification of waste cooking palm oil (WCPO) using $\mathrm{Sr} / \mathrm{ZrO}_{2}$ as the heterogeneous catalyst. The authors used response surface methodology [45] to find the maximum methyl ester yield $79.7 \%$ at the methanol-to-oil molar ratio $29: 1$, catalyst loading $2.7 \mathrm{wt} \%$, reaction time $87 \mathrm{~min}$ and reaction temperature $115.5^{\circ} \mathrm{C}$. Melero et al. [33] continuously produced biodiesel from WCO on a packed-bed reactor. The authors used the agglomerated Zr-SBA-15 material with bentonite clay to form a macroscopic structured catalyst with particle sizes of $1.5 \mathrm{~mm}$. The Zr-SBA-15/bentonite catalyst in pellet form was highly active in the continuous flow. It can produce a FAME yield of ca. $96 \%$ at $210{ }^{\circ} \mathrm{C}$ and 70 bar with a methanol-to-oil molar ratio of 50:1 and a residence time of $30 \mathrm{~min}$. Wen et al. [43] studied $\mathrm{TiO}_{2}-\mathrm{MgO}$ mixed oxides for biodiesel synthesis from WCO. The authors concluded that the best catalyst was MT-1-923, which comprises an $\mathrm{Mg} / \mathrm{Ti}$ molar ratio of 1 and is calcined at $923 \mathrm{~K}$, based on an assessment of the activity and stability of the catalyst. For the MT-1-923, the catalytic activity decreased slowly within the reuse processes.

\section{Heterogeneous Acid Catalyst}

Heterogeneous acid catalysts have the potential to replace strong liquid acids to eliminate corrosion problems and the consequent environmental hazards posed by liquid acids [46]. Some researchers have succeeded in converting biodiesel from WCO using these catalysts. Lou et al. [36] used carbohydrate-derived solid acid catalysts, which are insoluble in the tested solvents and liquid reactants (water, methanol, n-hexane, $\mathrm{t}$ butanol, oleic acid, triolein and WCO). The carbohydrate-derived catalysts prepared under optimized conditions displayed much higher activities than typical sulfated zirconia and niobic acid for both esterification and transesterification. Starch-derived catalysts are highly effective in converting high FFA-containing waste oils to biodiesel by simultaneous esterification and transesterification. The starch-derived catalyst is very effective in producing biodiesel of about $92 \%$ after $8 \mathrm{hr}$ from WCO containing 27.8 wt $\%$ FFA. This catalyst has very excellent operational stability and has potential as a heterogeneous strong acid catalyst. Jacobson et al. [34] sought the best solid acid catalyst for the simultaneous transesterification and esterification reactions of different types of solid acid catalysts.

Zinc stearate immobilized on silica gel was found to be the most active and stable heterogeneous catalyst under the optimized conditions of reaction temperature of $200{ }^{\circ} \mathrm{C}$, stirring speed of $600 \mathrm{rpm}, 1: 18$ molar ratio of oil to alcohol, and $3 \% \mathrm{w} / \mathrm{w}$ catalyst loading, producing a maximum ester content of $98 \mathrm{wt} \%$. It was reused many times without any loss. Georgogianni et al. [38] studied the transesterification reaction of soybean frying oil with methanol, in the presence of different heterogeneous catalysts (Mg MCM-41, Mg-Al hydrotalcite, and $\mathrm{K}+$ impregnated zirconia), using low frequency ultrasonication $(24 \mathrm{kHz})$ and mechanical stirring $(600 \mathrm{rpm})$ for the production of biodiesel fuel. In particular, $\mathrm{Mg}$ - $\mathrm{Al}$ hydrotalcite showed the highest conversion (97\%). Every catalyst has its own advantages and drawbacks depending on its undesirable compounds, especially FFA and water [1]. Table 2 lists the advantages and drawbacks of heterogeneous base catalysts and heterogeneous acid catalysts used in the transesterification of WCOs. 


\section{FUTURE DIRECTIONS}

In general, researchers have argued that the use of heterogeneous catalysts in the transesterification process of WCOs have good prospects for the future. WCO is a very appropriate feedstock for biodiesel production because it is cheaper and can overcome the problem of environmental disposal. However, many obstacles must be considered, including the absence of a systematic method of collecting WCOs from households, restaurants, hotels and the food industry. Talebian-Kiakalaieh et al. [18] stated that more than $80 \%$ of WCO is produced by households. This is a huge amount in utilizing WCO as a raw material in the production of biodiesel through transesterification.

Table 2. The advantages and drawbacks of heterogeneous base catalysts and heterogeneous acid catalysts used in the transesterification of WCOs [4, 23].

\begin{tabular}{|c|c|}
\hline Advantages & Drawbacks \\
\hline \multicolumn{2}{|l|}{ Heterogeneous base catalyst } \\
\hline $\begin{array}{l}\text { - Relatively faster reaction rate than } \\
\text { acid-catalyzed transesterification }\end{array}$ & $\begin{array}{l}\text { - Poisoning of the catalyst when exposed to } \\
\text { ambient air }\end{array}$ \\
\hline $\begin{array}{l}\text { - Reaction can occur under mild reaction } \\
\text { conditions and is less energy intensive }\end{array}$ & $\begin{array}{l}\text { - Sensitive to FFA content in the oil due to } \\
\text { its basic property }\end{array}$ \\
\hline $\begin{array}{l}\text { - Easily separated from the reaction } \\
\text { mixture without the use of water as the } \\
\text { cleaning agent }\end{array}$ & $\begin{array}{l}\text { - Soap will be formed if the FFA content in } \\
\text { the oil is more than } 2 \mathrm{wt} . \% \\
\text { - Too much soap formation will decrease }\end{array}$ \\
\hline $\begin{array}{l}\text { - High possibility of reusing and } \\
\text { regenerating the catalyst }\end{array}$ & $\begin{array}{l}\text { the biodiesel yield and cause problems } \\
\text { during product purification }\end{array}$ \\
\hline - A less corrosive character & - Leaching of catalyst active sites may result \\
\hline $\begin{array}{l}\text { - Leans towards being safer, cheaper } \\
\text { - More environmentally friendly }\end{array}$ & in contamination \\
\hline \multicolumn{2}{|l|}{ Heterogeneous acid catalyst } \\
\hline $\begin{array}{l}\text { - Insensitive to FFA and water content in } \\
\text { the oil }\end{array}$ & $\begin{array}{l}\text { - Complicated catalyst synthesis procedures } \\
\text { lead to higher cost }\end{array}$ \\
\hline $\begin{array}{l}\text { - Preferred-method if low-grade oil is } \\
\text { used }\end{array}$ & $\begin{array}{l}\text { - Normally, high reaction temperature, high } \\
\text { alcohol to oil molar ratio and long reaction }\end{array}$ \\
\hline $\begin{array}{l}\text { - Esterification and transesterification } \\
\text { occur simultaneously }\end{array}$ & $\begin{array}{l}\text { time are required } \\
\text { • Energy intensive }\end{array}$ \\
\hline $\begin{array}{l}\text { - Easy separation of catalyst from } \\
\text { product }\end{array}$ & $\begin{array}{l}\text { - Leaching of catalyst active sites may result } \\
\text { in contamination }\end{array}$ \\
\hline
\end{tabular}

From the technical point of view, a heterogeneous catalyst can be easily separated from the reaction mixture and can be reused several times with consistent activity, so that it can be developed as a good catalyst for industrial biodiesel processes. It presents good catalytic activity in powder form, opening the possibility of undertaking a continuous catalytic process for biodiesel production with both slurry and fixed bed configuration reactors, with the capability of using the residue frying oil as inexpensive feedstock, contributing also to the elimination of residue together with the production of biodiesel [23]. From the economic point of view, the heterogeneous acid-catalyzed process is an efficient technology in producing biodiesel directly from low cost 
feedstock, such as WCO the price of which is two to three times cheaper than vegetable oils, and it also reduces the cost of waste product removal and treatment. However, the research into FAME from WCO using these types of catalyst is limited [18]. Heterogeneous catalysts have drawbacks, namely their low reaction rates in comparison with the homogeneous process in biodiesel production [47], their unsuitability with very high FFA content feedstock and the production of soaps [19].

Another obstacle associated with the development of heterogeneous base catalysts is their ability to tolerate the FFA content of feedstock under mild reaction conditions and their reusability. For this reason, researchers have developed catalysts, such as bifunctional heterogeneous catalysts, that can simultaneously conduct the esterification of FFAs and transesterification of triglycerides for sustainable biodiesel production technology. The bifunctional catalyst can act as an acid and base at the same time and can be easily modified to introduce the desired physicochemical properties so that the presence of FFAs or water does not adversely affect the reaction steps during the transesterification process $[20,48]$. To obtain the optimal economic value, it is necessary to choose the appropriate feedstock, process and catalyst. Biodiesel production from WCO as the feedstock can be optimized with a combination of the lowest cost of heterogeneous catalyst and low energy consumption for processing, such as microwave irradiation $[49,50]$.

\section{CONCLUSIONS}

From this review, it has been learnt that the use of heterogeneous catalysts in biodiesel production via transesterification using $\mathrm{WCO}$ as a raw material is attracting more attention and is becoming more attractive. Researchers should concentrate on the application of such catalysts in terms of both economic and environmental terms. A number of researchers have successfully produced biodiesel using these solid catalysts. Some of them recommend the best catalysts in biodiesel production. Nonetheless, researchers always strive to improve the biodiesel process economically using environmentally friendly catalysts and selecting the best process technology.

\section{ACKNOWLEDGMENT}

The first author would like to thank the Governor of South Sulawesi Indonesia on scholarships to continue his education at the University of Technology Malaysia.

\section{REFERENCES}

[1] Kulkarni MG, Dalai AK. Waste cooking oil an economical source for biodiesel: a review. Industrial \& Engineering Chemistry Research. 2006;45:2901-13.

[2] Prafulla D P, Veera Gnaneswar G, Harvind K R, Tapaswy M, Shuguang D. Biodiesel production from waste cooking oil using sulfuric acid and microwave irradiation processes. Journal of Environmental Protection. 2012;3:107 - 13.

[3] Zhou Z, Kumar R, Thakur S, Rudnick L, Schobert H, Lvov S. Direct oxidation of waste vegetable oil in solid-oxide fuel cells. Journal of Power sources. 2007;171:856-60.

[4] Lam MK, Lee KT, Mohamed AR. Homogeneous, heterogeneous and enzymatic catalysis for transesterification of high free fatty acid oil (waste cooking oil) to biodiesel: a review. Biotechnology Advances. 2010;28:500-18. 
[5] No SY. Inedible vegetable oils and their derivatives for alternative diesel fuels in CI engines: a review. Renewable and Sustainable Energy Reviews. 2011;15:131-49.

[6] Lanzafame R. Water injection effects in a single-cylinder CFR engine. SAE Technical Paper No. 1999-01-0568; 1999.

[7] Demirbas A. Biodiesel a realistic fuel alternative for diesel engines. London: Springer; 2008.

[8] Soon LB, M. Rus AZ, Hasan S. Continuous biodiesel production using ultrasound clamp on tubular reactor. International Journal of Automotive and Mechanical Engineering. 2013;8:1396-405.

[9] Vashist D, Ahmad M. Statistical Analysis of Diesel Engine Performance for Castor and Jatropha Biodiesel-Blended Fuel. International Journal of Automotive and Mechanical Engineering. 2014;10:2155-69.

[10] Bajpai D, Tyagi V. Biodiesel: source, production, composition, properties and its benefits. Journal of Oleo Science. 2006;55:487-502.

[11] Abbaszadeh A, Ghobadian B, Najafi G, Yusaf T. An experimental investigation of the effective parameters on wet washing of biodiesel purification. International Journal of Automotive and Mechanical Engineering. 2014;9:152537.

[12] Azman SR, Ismail M, Kadhum AAH, Yaakob Z. The Performance of Monolithic Structured Calcium Oxide for Biodiesel. International Journal of Automotive and Mechanical Engineering. 2014;10:1959-70.

[13] Kumaran P, Gopinathan M, Kantharrajan S. Combustion Characteristics of Improved Biodiesel in Diffusion Burner. International Journal of Automotive and Mechanical Engineering. 2014;10:2112-21.

[14] Rahim R, Mamat R, Taib MY, Abdullah AA. Influence of fuel temperature on a diesel engine performance operating with biodiesel blended. Journal of Mechanical Engineering and Sciences. 2012;2:226-36.

[15] Nasir N, Daud Z. Performance of Aluminium Sulphate and Polyaluminium Choloride in Biodiesel Wastewater. Journal of Mechanical Engineering and Sciences. 2014;7:1189-95.

[16] Demirbas A. Progress and recent trends in biodiesel fuels. Energy Conversion and Management. 2009;50:14-34.

[17] Singh SP, Singh D. Biodiesel production through the use of different sources and characterization of oils and their esters as the substitute of diesel: a review. Renewable and Sustainable Energy Reviews. 2010;14:200-16.

[18] Talebian-Kiakalaieh A, Amin NAS, Mazaheri H. A review on novel processes of biodiesel production from waste cooking oil. Applied Energy. 2013;104:683710.

[19] Borges ME, Díaz L. Recent developments on heterogeneous catalysts for biodiesel production by oil esterification and transesterification reactions: a review. Renewable and Sustainable Energy Reviews. 2012;16:2839-49.

[20] Farooq M, Ramli A, Subbarao D. Biodiesel production from waste cooking oil using bifunctional heterogeneous solid catalysts. Journal of Cleaner Production. 2013;59:131-40.

[21] Refaat AA. Biodiesel production using solid metal oxide catalysts. International Journal of Environmental Science \& Technology. 2011;8:203-21. 
[22] Yaakob Z, Mohammad M, Alherbawi M, Alam Z, Sopian K. Overview of the production of biodiesel from waste cooking oil. Renewable and Sustainable Energy Reviews. 2013;18:184-93.

[23] Borges ME, Díaz L. Catalytic packed-bed reactor configuration for biodiesel production using waste oil as feedstock. BioEnergy Research. 2013;6:222-8.

[24] Roschat W, Kacha M, Yoosuk B, Sudyoadsuk T, Promarak V. Biodiesel production based on heterogeneous process catalyzed by solid waste coral fragment. Fuel. 2012;98:194-202.

[25] Kouzu M, Kasuno T, Tajika M, Sugimoto Y, Yamanaka S, Hidaka J. Calcium oxide as a solid base catalyst for transesterification of soybean oil and its application to biodiesel production. Fuel. 2008;87:2798-806.

[26] Brito A, Borges M, Garin M, Hernández A. Biodiesel production from waste oil using Mg- Al layered double hydroxide catalysts. Energ Fuel. 2009;23:2952-8.

[27] Dehkordi AM, Ghasemi M. Transesterification of waste cooking oil to biodiesel using $\mathrm{Ca}$ and $\mathrm{Zr}$ mixed oxides as heterogeneous base catalysts. Fuel Processing Technology. 2012;97:45-51.

[28] Balakrishnan K, Olutoye M, Hameed B. Synthesis of methyl esters from waste cooking oil using construction waste material as solid base catalyst. Bioresource Technology. 2013;128:788-91.

[29] Omar WNNW, Amin NAS. Optimization of heterogeneous biodiesel production from waste cooking palm oil via response surface methodology. Biomass and Bioenergy. 2011;35:1329-38.

[30] Chin L, Hameed B, Ahmad A. Process optimization for biodiesel production from waste cooking palm oil (Elaeis guineensis) using response surface methodology. Energy and Fuels. 2009;23:1040-4.

[31] Buasri A, Ksapabutr B, Panapoy M, Chaiyut N. Biodiesel production from waste cooking palm oil using calcium oxide supported on activated carbon as catalyst in a fixed bed reactor. Korean Journal of Chemical Engineering. 2012;29:170812.

[32] Anastopoulos G, Dodos G, Kalligeros S, Zannikos F. Biodiesel production by ethanolysis of various vegetable oils using calcium ethoxide as a solid base catalyst. International Journal of Green Energy. 2013;10:468-81.

[33] Melero JA, Bautista LF, Iglesias J, Morales G, Sánchez-Vazquez R. Production of biodiesel from waste cooking oil in a continuous packed bed reactor with an agglomerated Zr-SBA-15/bentonite catalyst. Applied Catalysis B: Environmental. 2014;145:197-204.

[34] Jacobson K, Gopinath R, Meher LC, Dalai AK. Solid acid catalyzed biodiesel production from waste cooking oil. Applied Catalysis B: Environmental. 2008;85:86-91.

[35] Guan G, Kusakabe K, Yamasaki S. Tri-potassium phosphate as a solid catalyst for biodiesel production from waste cooking oil. Fuel Processing Technology. 2009;90:520-4.

[36] Lou WY, Zong MH, Duan ZQ. Efficient production of biodiesel from high free fatty acid-containing waste oils using various carbohydrate-derived solid acid catalysts. Bioresource Technology. 2008;99:8752-8.

[37] Pugnet V, Maury S, Coupard V, Dandeu A, Quoineaud A-A, Bonneau J-L, et al. Stability, activity and selectivity study of a zinc aluminate heterogeneous catalyst for the transesterification of vegetable oil in batch reactor. Applied Catalysis A: General. 2010;374:71-8. 
[38] Georgogianni KG, Katsoulidis AP, Pomonis PJ, Kontominas MG. Transesterification of soybean frying oil to biodiesel using heterogeneous catalysts. Fuel Processing Technology. 2009;90:671-6.

[39] Liu W, Yin P, Liu X, Chen W, Chen H, Liu C, et al. Microwave assisted esterification of free fatty acid over a heterogeneous catalyst for biodiesel production. Energy Conversion and Management. 2013;76:1009-14.

[40] Boffito DC, Pirola C, Galli F, Di Michele A, Bianchi CL. Free fatty acids esterification of waste cooking oil and its mixtures with rapeseed oil and diesel. Fuel. 2013;108:612-9.

[41] Li M, Zheng Y, Chen Y, Zhu X. Biodiesel production from waste cooking oil using a heterogeneous catalyst from pyrolyzed rice husk. Bioresource Technol. 2014; $154: 345-8$.

[42] Park YM, Lee DW, Kim DK, Lee JS, Lee KY. The heterogeneous catalyst system for the continuous conversion of free fatty acids in used vegetable oils for the production of biodiesel. Catalysis Today. 2008;131:238-43.

[43] Wen Z, Yu X, Tu ST, Yan J, Dahlquist E. Biodiesel production from waste cooking oil catalyzed by $\mathrm{TiO} 2-\mathrm{MgO}$ mixed oxides. Bioresource Technology. 2010;101:9570-6.

[44] Zhang X, Li J, Chen Y, Wang J, Feng L, Wang X, et al. Heteropolyacid nanoreactor with double acid sites as a highly efficient and reusable catalyst for the transesterification of waste cooking oil. Energy and Fuels. 2009;23:4640-6.

[45] Boersma BJ. A 6th order staggered compact finite difference method for the incompressible Navier-Stokes and scalar transport equations. Journal of Computational Physics. 2011;230:4940-54.

[46] Helwani Z, Othman MR, Aziz N, Kim J, Fernando WJN. Solid heterogeneous catalysts for transesterification of triglycerides with methanol: a review. Applied Catalysis A: General. 2009;363:1-10.

[47] Jin L, Zhang Y, Dombrowski JP, Chen C-H, Pravatas A, Xu L, et al. ZnO/La 2 O 2 CO 3 layered composite: a new heterogeneous catalyst for the efficient ultra-fast microwave biofuel production. Applied Catalysis B: Environmental. 2011;103:200-5.

[48] Endalew AK, Kiros Y, Zanzi R. Heterogeneous catalysis for biodiesel production from Jatropha curcas oil (JCO). Energy. 2011;36:2693-700.

[49] Motasemi F, Ani FN. A review on microwave-assisted production of biodiesel. Renewable and Sustainable Energy Reviews. 2012;16:4719-33.

[50] Ani FN, Bakheit Elhameed A. Heterogeneous Microwave Irradiation Biodiesel Processing of Jatropha Oil. Applied Mechanics and Materials. 2014; 554:500-4. 